\title{
НРАВСТВЕННОЕ ПОВЕДЕНИЕ СОВРЕМЕННОЙ МОЛОДЕЖИ В СИТУАЦИИ КРИЗИСА
}

\section{MORAL BEHAVIOR OF YOUTH IN A CRISIS SITUATION}

\author{
N. Trofimova \\ E. Goncharenko
}

Summary: In the context of the COVID-19 pandemic, society is in the stage of alostatic overload - the stressor exceeds individual copying capabilities. Global crisis conditions become a kind of moral test for young people on the stability of their worldview system. The authors of the article systematized in seven groups the specific mechanisms of loosening the psychological construct of moral values in a pandemic; substantiated that moral qualities are the foundation of the triad of psychological health of young people (psychosomatic, mental and spiritual); found that selfish motivation can cause a regression of moral values, but further conclusions require more extensive research, the urgency of which is extremely urgent due to the fact that the rehabilitation of society after a pandemic will depend on the stability of moral values of young people.

Keywords: COVID-19 pandemic, crisis conditions, moral qualities, morality, selfish motivation, psychological health.
Трофимова Наталья Борисовна

Д.nсх.н., профессор, Воронежский государственный педагогический университет

n_trofimova@mail.ru

Гончаренко Елена Семеновна Старший преподаватель, Воронежский государственный педагогический университет elena_sg@inbox.ru

Аннотация: В условиях пандемии COVID-19 социум находится в стадии аллостатической перегрузки - стрессор превышает индивидуальные возможности копинга. Глобальные кризисные условия становятся своеобразным моральным тестом для молодых людей на устойчивость их системы мировоззрения. Авторы статьи систематизировали в виде семи групп специфические механизмы расшатывания психологического конструкта нравственного поведения в условиях пандемии; обосновали, что нравственные качества это фундамент триады психологического здоровья молодых людей (психосоматического, психического и духовного); выяснили, что эгоистическая мотивация может стать причиной регресса моральных ценностей, однако для дальнейших выводов требуются более масштабные исследования, насущность которых крайне актуализирована ввиду того, что от устойчивости нравственного поведения молодых людей будет зависеть эффективность реабилитации социума после пандемии.

Ключевые слова: пандемия COVID-19, кризисные условия, нравственное поведение, моральные качества, эгоистическая мотивация, психологическое здоровье.

Пандемия COVID-19, которая начала оказывать ощутимое психологическое воздействие на население мира в 2020 году - это очередное значительное испытание для молодых людей, которые на стыке веков уже и так столкнулись со стремительной (и потому, деструктивной) цифровизацией, недоступным жильем и финансовым дефицитом, студенческими долгами, политической нестабильностью, экономическим кризисом. Thakur V., Jain А. (2020) в своем исследовании количества самоубийств молодых людей, ассоциированных с пандемией пишут, что этот стрессор стал последней каплей в деструкции психического здоровья некоторой части населения [7].

Цель данной работы - исследовать риски регресса системы моральных ценностей молодых людей в ситуации пандемии.

Сейчас мы находимся в стадии алостатической перегрузки - стрессор превышает индивидуальные возможности копинга, а это означает, что дистресс может начать оказывать влияние на нравственное поведение. Психологические стрессоры при изоляции: 
1. разочарование, связанное с потерей привычного режима (социальные ограничения);

2. недостаток или отсутствие дохода; отсутствие доступа к регулярной медицинской помощи;

3. недостаточная информация (отсутствие или необъективность информации от учреждений здравоохранения, непонятные указания, отсутствие прозрачности);

4. страх за свое здоровье, карьеру (обучение), будущее (будущее своей семьи);

5. большая длительность карантина [5].

Реакция на данные стрессоры нашла свое отображение в исследовании Е.В. Федосенко (2020): по результатам анкеты «Психологические ресурсы человека в ситуации вынужденной изоляции» на вопрос: «Отметьте те реакции, которые вы испытывали в связи с текущей ситуацией пандемии (анкетирование проводилось во время первого срока карантина: с 30 марта по 5 апреля 2020 года, п=784)» в первую тройку вошли следующие реакции: страх у 47,3\% (372 из 784 респондентов), апатия у 22,2 \% (174 из 784) и ступор у 14,5 (114 из 784) [10].

Мы считаем, что такие результаты получены из-за того, что молодые люди ощущают институциональную неспособность государства удовлетворить их базовые потребности, поэтому все чаще только социальные сети создают видимость единого сообщества, в реальности же социальные коммуникации отличаются разрозненностью и отсутствием моральной основы. В условиях пандемии изолятивные меры масштабны, что позволяет легко избегать людей, которые считаются неудобными. Это условие приводит к окончательному разрушению общественных связей; кроме того, создание курируемого электронного мира искажает восприятие реальности, поведения других людей и того, что важно для общества в данный кризисный период [4].

Важно понимать, что нравственные качества есть фундамент триады психологического здоровья молодых людей. Сегодня мы можем наблюдать по всему миру колоссальное психическое напряжение в обществе, связанное с пандемией коронавируса. Чтобы в таких условиях быть способным к конструктивной самореализации, человек должен быть физически и психологически здоровым, иметь духовный иммунитет для противостояния разрушительным внешним факторам. Однако, в последние годы произошли серьезные изменения в социокультурной ситуации, в экологической, экономической жизни общества, что бесспорно отражается на психологическом климате России и на психическом здоровье молодых людей.

По нашему мнению, именно полноценная сформированность конструктивных нравственных качеств у молодых людей, определяет соответствующие типы их психологического здоровья, которые могут демонстрировать стабильность или нестабильность в кризисных условиях: психосоматическое, психическое и духовное здоровье. Мы бы дополнили данную триаду отдельным экзистенциальным уровнем, который функционирует посредством обретения смысла жизни с помощью урегулирования смысловой и моральной составляющей внутреннего и внешнего мира.

Ключевым критерием психологического здоровья выступает именно нравственное поведение, так как личность может иметь все признаки психического здоровья, но быть деформированной, как личность [2]. По нашему мнению, именно ценностные ориентации следует рассматривать как индивидуальные формы репрезентации надындивидуальных ценностей, так как понятие «ценности» и «ценностные ориентации» различаются и по параметру «общее - индивидуальное», и по параметру «реально действующее - рефлексивно сознательное» в зависимости от того, признается ли наличие индивидуально-психологических форм существования ценностей, отличных от их присутствия в сознании.

Важным моментом, оказывающим давление на систему моральных ценностей молодых людей в ситуации пандемии стал информационный стресс (который бывает двух типов: информационная недостаточность и информационная избыточность) в виде переизбытка негативной информации [9].

В современных условиях пандемии, СМИ нагнетают массовое психическое напряжение относительно карантина и его последствий и наиболее восприимчивы к данной информации именно молодые люди, так как их возрастной категории свойственны оптимистичные надежды на будущее, которые в нынешней реальности оказываются под угрозой. Формируется негативная установка: молодые люди начинают враждебно относятся к больным и другим людям в целом (как потенциальным носителям вируса) [6].

Отметим специфические механизмы расшатывания системы моральных ценностей молодых людей в условиях пандемии. Коронавирус стал своеобразным моральным тестом для молодых людей на человечность, на любовь к ближним и склонность к взаимопомощи. Глобальные риски и кризисные условия воспринимаются молодежью несколько особенно, поэтому их реакцию (в лонгитюдном измерении последствий для личностной целостности) тяжело спрогнозировать. Мы предлагаем выделить 7 специфическим механизмов, способных пошатнуть сформированные нравственные ценности у молодых людей в условиях пандемии.

Во-первых, глобальные риски, связанные с сегодняшней пандемией, не подтверждаются повседневным опы- 
том, не обнаруживаются органами чувств. Исследования свидетельствуют, что редкость или отсутствие тех или иных событий в личном опыте приводят к недооценке их вероятности (именно поэтому, молодые люди размышляют о коронавирусе не так, как индивиды старшего возраста). Стоит заметить, что скоротечность развития нынешних событий не оставила времени на его осмысление и организацию противодействия. Поэтому возник психологический парадокс: для подготовки к таким кризисам молодежи не хватает опыта и воображения, а при их возникновении - наиболее вероятны шаблонные реакции без возможности их корректировки, либо рационального обучения на собственных действиях [5].

Во-вторых, кризисы и риски, сопровождающие пандемию, воспринимаются как отдаленные во времени, что приводит к ряду когнитивных искажений у молодых людей: осмысление в абстрактных категориях, нечувствительность к масштабу потенциальных жертв, неготовность личности включать кризисные события в свои жизненные планы (например, помогать пожилым людям в условиях карантина). Карантин часто является неприятным опытом для тех, кто проходит через него: разлука с близкими, потеря свободы, неуверенность в отношении состояния болезни и скука могут иногда вызывать драматические последствия (самоубийства, агрессию, судебные процессы, дисгармоничные семейные отношения, конфликты, увеличение случаев семейного насилия и пр.) [2].

В-третьих, переживание глобальных рисков, связанных с пандемией, затрудняет поиск способов предотвращения их последствий, что парадоксальным образом повышает угрозу всеобщей безопасности, ведь именно молодые люди на сегодняшний день формируют значительную часть системы здравоохранения, волонтерской, социальной и политической деятельности.

В-четвертых, защитные механизмы при глобальных кризисах у молодёжи характеризуются противоположностью (биполярность) в той же мере психической силы, в которой находятся полярные эмоции, которые лежат в их основе (радость - печаль, страх - гнев, принятие отвращение, ожидание - удивление). Таким образом, восемь базисных механизмов можно свести к четырем биполярным парам: реактивное образование - компенсация, подавление - замещение, отрицание - проекция, интеллектуализация - регрессия. Поскольку защитные механизмы являются производными эмоций, то они, по аналогии с эмоциями, при длительном существовании могут приводить к формированию новых черт характера и трансформации нравственного поведения [4].

В-пятых, биологический источник глобальных рисков пандемии способен к самовоспроизведению (цепная реакция, прогрессирующее саморазвитие), то есть проис- ходит нарастание, интенсификация кризисных условий. С психологической точки зрения это означает, что в процессе проявления риска усиливаются фаталистические установки.

В-шестых, глобальные риски пандемии имеют негативные последствия в аспекте актуализации деструктивного пути развития защитных механизмов молодёжи, которые заключаются в следующем:

1. они мешают личности осознать свои ошибки и увидеть со стороны собственные черты характера, проанализировать изменившиеся мотивы нравственного поведения;

2. они могут искажать содержание событий и переживаний, чтобы не нанести вред психике личности;

3. они лишают человека возможности активно влиять на ситуацию и быть в состоянии устранить источник переживаний путём рационального мышления и образования логических цепочек.

В-седьмых, ход восприятия внешнего кризиса молодёжью, характеризуется наличием микроизменений, которые аккумулируются личностью в предыдущем стабильном периоде и распределяют его на фазы: предкритическую, критическую и посткритическую. Предкритическая - обусловлена возникновением определенных противоречий между составляющими социального развития личности и его нравственным поведением. Критическая - когда противоречия обостряются и достигают своей кульминации. Посткритическая фаза наступает когда личность переходит к новому типу поведения, которое адаптировано под ситуацию кризиса и его последствий. Именно в посткритической фазе важно, чтобы моральные ценности укрепились, а не обратились в регрессивное состояние.

Важно понимать, что эгоистическая мотивация, как правило, является причиной регресса нравственных качеств молодежи. Для определения актуальной ситуации проявления эгоистической мотивации в условиях пандемии лиц молодого возраста, мы провели исследование эгоизма как ключевой черты, которая в нынешней ситуации подрывает фундамент нравственных ценностей. Данная психологическая категория была исследована при помощи трех инструментов: опросник Г. Кеттела; опросник «Свойства характера» (Т. Лири); методика «свободного эгоизма» (К. Муздибаева). Было проведено исследование на произвольной выборке молодежи (17 25 лет) - 27 человек, среди которых 13 - женского пола и 14 - мужского.

Результаты показали, что исследуемым лицам молодого возраста не присуща эгоистическая направленность как базовая черта («Свойства характера» Т. Лири), однако по индивидуальным результатам уровень эгои- 
стической тенденции составляет - 35,9\%, что может быть вызвано текущими жизненными кризисами в условиях пандемии. Специфика результатов по трем методикам заключается в том, что по опроснику Г. Кеттела есть всеобщая направленность к ненормативному поведению, однако, мы лишь можем сделать предположение, что так происходит из-за того, что всем исследуемым на данном этапе присущ профессиональный кризис, который провоцирует некоторый регресс нравственных ценностей и в связи с этим затруднено внимание к нуждам других (так как под угрозой находится удовлетворение собственных). По шкале «свободного эгоизма» К. Муздибаева характерно крайнее проявление эгоизма, однако, даже в условиях пандемии, это лишь подчеркивает специфику данного возраста.

По нашему мнению, эгоизм оказывает значимое влияние на нравственные ценности, однако, ключевым регулятором поведения является мораль, способная контролировать и подавлять эгоистичные проявления. Мораль ограничивает свободу бесконтрольного эгоизма, свободу пагубных социальных влияний и даже политического воздействия (именно поэтому политика часто стремится освободиться от нее с помощью высоконравственных лозунгов, которые скрывают ее настоящую цель). Мораль опирается на «санкции» совести, которая разделяет мораль на этику убеждений и этику ответственности. Если этика убеждения ближе к морали, то этика ответственности предполагает совсем другое реакцию на конкретные кризисные обстоятельства и их последствия, внутреннюю ответственность за результаты своих действий, готовность предотвратить страдания окружающих людей. При этом, существует огромный индивидуальный разброс в способности молодых людей справляться с последствиями пандемии, учитывая раз- личный уровень психического здоровья и сформировавшегося нравственного поведения. Тот, кто уже имеет проблемы с социальной тревогой, депрессией, одиночеством, токсикоманией или другими проблемами - будет особенно уязвим и гораздо легче трансформируется в негативном аспекте нравственности.

\section{Зак^ючение}

Итак, все те изменения, которые происходят в условиях пандемии, непосредственно влияют на ценностные приоритеты молодежи, инициируя тенденцию к развитию эгоистической мотивации, так как новые социально-экономические условия требуют от данной социальной группы совсем других качеств, новых мировоззренческих и нравственных ориентиров. Кроме того, в условиях переходного трансформационного общества актуализация дальнейшего изучения ценностных предпочтений молодых людей вызвана, прежде всего, практической необходимостью, ведь от того, с какими ценностями молодежь будет жить в будущем, будет зависеть реабилитация нашего общества после пандемии.

Несмотря на пандемическую угрозу, молодые люди могут реализовывать свои лучшие нравственные ценности путем участия в мероприятиях по оказанию необходимой социальной, психопрофилактической и психогигиенической помощи уязвимым группам населения; важное значение имеет психологическая подготовка молодых людей к волонтерской деятельности. Для организации оптимального поведения молодых людей в условиях пандемии COVID-19, важно опираться на этические основы рационального гуманизма, базис которого формирует нравственные ценности в кризисных условиях.

\section{ЛИТЕРАТУРА}

1. Arden M.A., Chilcot J. Health psychology and the coronavirus (COVID-19) global pandemic: A call for research //British Journal of Health Psychology. - 2020. - 320 C.

2. Conway L.G., Woodard S.R., Zubrod A. Social psychological measurements of COVID-19: Coronavirus perceived threat, government response, impacts, and experiences questionnaires. $-2020 .-418 \mathrm{c}$.

3. Graham A. et al. Faith in Trump, Moral Foundations, and Social Distancing Defiance During the Coronavirus Pandemic //Moral Foundations, and Social Distancing Defiance During the Coronavirus Pandemic (April 22, 2020). - 2020. - 298 C.

4. Harper C.A. et al. Functional fear predicts public health compliance in the COVID-19 pandemic //International journal of mental health and addiction. - 2020 - 177 c.

5. Shi W., Hall B.J. What can we do for people exposed to multiple traumatic events during the coronavirus pandemic? //Asian Journal of Psychiatry. $-2020 .-200 \mathrm{C}$.

6. Sood S. Psychological effects of the Coronavirus disease-2019 pandemic//Research \& Humanities in Medical Education. $-2020 .-$ T. 7. $-529 \mathrm{C}$.

7. Thakur V., Jain A. COVID 2019-suicides: A global psychological pandemic //Brain, behavior, and immunity. $-2020 .-740 \mathrm{C}$.

8. Ключникова Т.Н. Технологии формирования ценностей молодежи в пространстве социальных сетей //Проблемы научной мысли. - 2019. - Т. 1. - №. 2. - 465 с.

9. уупна Н.А. Пандемия коронавируса: метафорическое освоение новой реальности //Аксиологические аспекты современных филологических исследований. - Екатеринбург, 2020. - 2020. - 350 с.

10. Федосенко Е.В. Жизнь после карантина: психология смыслов и коронавирус COVID-19 //Психологические проблемы смысла жизни и акме. - 2020. - №. XXV. $-388 \mathrm{c}$. 